\title{
Corporate Criminal Responsibility for Human Rights Violations: Jurisdiction and Reparations
}

Kenneth S. Gallant

ksgallant@ualr.edu

Follow this and additional works at: https://lawrepository.ualr.edu/faculty_scholarship

Part of the Criminal Law Commons, Human Rights Law Commons, and the International Law Commons

\section{Recommended Citation}

Kenneth S. Gallant, Corporate Criminal Responsibility for Human Rights Violations: Jurisdiction and Reparations, in Prosecuting Corporations for Violations of International Criminal Law: Jurisdictional Issues 47 (Maklu 2017).

This Article is brought to you for free and open access by Bowen Law Repository: Scholarship \& Archives. It has been accepted for inclusion in Faculty Scholarship by an authorized administrator of Bowen Law Repository: Scholarship \& Archives. For more information, please contact mmserfass@ualr.edu. 


\title{
CORPORATE CRIMINAL RESPONSIBILITY FOR HUMAN RIGHTS VIOLATIONS: JURISDICTION AND REPARATIONS
}

\author{
By Kenneth S. Gallant*
}

\section{Executive Summary}

Modern prosecutions at international criminal courts and tribunals have demonstrated that the resources available for reparations and restitution from individuals convicted of core international crimes is grossly insufficient to meet even basic restitutionary needs. Most of the wealth that might exist as a result of international crimes is likely to be in the hands of corporations or other artificial persons who have gained property and income through human rights violations. None of the international criminal courts and tribunals (ICCTs) has adjudicative jurisdiction over artificial persons of any sort, so that any progress on restitution and restorative justice must come through national tribunals. This applies to both core international crimes and the broader category of human rights treaty crimes which are outside the authority of ICCTs.

Many obstacles to reparations for human rights violations related to business activities arise from the international and national laws of jurisdiction. Rules of prescriptive, adjudicative, and enforcement jurisdiction combine with substantive rules of criminal law to make adequate reparations for human rights related business crimes difficult to achieve.

The Guiding Principles on Business and Human Rights (the 'Ruggie Principles'), adopted by the United Nations Human Rights Council, address prevention, monitoring, and remediation of business participation in human rights abuses of all kinds. Application of several of the Principles can help states provide a jurisdictional framework for reparations for business-related human rights violations.

There are some signs of progress in recent decades. More states are now willing to exercise criminal jurisdiction over corporations. New human rights treaties require states to hold artificial persons liable for violations, criminally or otherwise. Objective territorial jurisdiction (sometimes called 'effects' jurisdiction) is ever more clearly permissible when outside activity directly causes criminal results in states. Finally, the rule against enforcing criminal law judgments across borders is beginning to decline, making the shielding of assets from claims for restitution and restorative justice through criminal proceedings much more difficult.

\footnotetext{
* Fulbright Scholar, Pluricourts Project on Legitimacy of the International Judiciary, University of Oslo, Norway; Permanent position: Professor, University of Arkansas at Little Rock Bowen School of Law, Little Rock, AR 72032 USA; +1-501-269-2319, ksgallant@ualr.edu. This work was partly supported by the Fulbright program, by the University of Arkansas at Little Rock Bowen School of Law, and by the Research Council of Norway through its Centres of Excellence funding scheme, project no. 223274
} 
Nonetheless, many obstacles to transnational enforcement of criminal judgments remain. Given trends in the international law of jurisdiction, it may turn out that civil judgments of restitution and reparation will be easier to obtain and enforce than criminal judgments.

\section{Introduction}

Jurisdiction features prominently in discussion of responsibility for international crimes, including responsibility of corporations and other artificial persons for these crimes. This is true both of the so-called 'core' international crimes (genocide, crimes against humanity, and war crimes) as well as the much broader set of crimes and human rights violations condemned in international treaty law.

The connection of jurisdictional issues and corporate responsibility to certain specific purposes of outlawing these acts is much less prominent. Of the many goals underlying criminalization, this report will consider only one, restitution or reparations for victims.

This report will cover two issues. First, it will examine how the international law of criminal jurisdiction either promotes or obstructs the use of criminal law to achieve reparative justice for victims of international crimes. Second, it will consider the national and international exercises of this jurisdiction necessary to implement the ability to provide reparations for corporate violations of human rights.

These two issues address the conditions necessary for reparations to be effective as part of a legal response to corporate violations of human rights. This report will address issues of the general part of criminal law, such as liability for the acts of others, to the extent that the National Reports demonstrate this is necessary. It will do the same for issues of corporate responsibility, such as the relationship between parent and subsidiary corporations, also raised in the National Reports. In fact, the shaping of these substantive doctrines by the law of jurisdiction is one of the more important developments that the National Reports reveal to us.

2.1 Corporate reparations for violations of internationally-recognized human rights: The UN framework

United Nations documents set out a framework for providing remedies for violations of international human rights law (the general law protecting human rights) and international humanitarian law (the law of armed conflict). This framework includes remedies for violations committed by corporations and other so-called 'legal persons.' These documents do not create any new international obligations for states, individuals, or business organizations. They are so-called 'international soft law' instruments. Yet these documents do include recommendations that states change their 'hard law' of criminal, administrative, and/or civil liability of corporations.

The first is the 2005 'Basic Principles and Guidelines on the Right to a Remedy and Reparation for Victims of Gross Violations of International Human Rights Law and Serious 
Violations of International Humanitarian Law, ${ }^{1}$ from the UN General Assembly. This took its inspiration from several treaties and other international documents creating or asserting a duty to provide for remedies for victims of violations of international human rights law and international humanitarian law. ${ }^{2}$ It recommended states use their national 'hard law' to provide this right to a remedy and reparation.

The second is the 'Guiding Principles on Business and Human Rights' ${ }^{3}$ adopted in 2011 by the UN Human Rights Council. This document is known as the 'Ruggie Principles' for the Special Representative of the Secretary General who developed them. Because they are aimed specifically at improving business practices, the Ruggie Principles are more specialized than the 2005 Basic Principles. Within the business context, the Ruggie Principles are more comprehensive, because they systematically address prevention of abuses as well as remedy. The Ruggie Principles also set out a definition of the 'human rights' being defended:

The responsibility of business enterprises to respect human rights refers to internationally recognized human rights - understood, at a minimum, as those expressed in the International Bill of Human Rights and the principles concerning fundamental rights set out in the International Labour Organization's Declaration on Fundamental Principles and Rights at Work. ${ }^{4}$

This technically leaves out violations of international humanitarian law. It is hard to imagine that there is any intention to leave the mass violence of armed conflict and related wrongs unremedied, especially since the 2005 UN Basic Principles addressed remedies for serious violations of international humanitarian law.

The Ruggie Principles do not set out a requirement of criminalization of corporate actions which violate international human rights. The question of what human rights violations in which corporations are implicated should be criminalized and what the elements of those

\footnotetext{
${ }^{1}$ UN Basic Principles and Guidelines on the Right to a Remedy and Reparation for Victims of Gross Violations of International Human Rights Law and Serious Violations of International Humanitarian Law, UNGA Res. 60/147 (2005) paras. 18-23 (the discussion in this Report will omit "guarantees of non-repetition," because these guarantees are more about prevention of subsequent abuse than remedying prior injury). For core international crimes, see Rome Statute of the International Criminal Court (1998) art 74(2) (restitution, compensation, rehabilitation). For the most recent consideration of the issue by the ICC, see Prosecutor $v$ Lubanga, Reparations Judgment with Amended Principles of Reparations and Reparations Order, ICC-01/0401/06 and Annex A (App Ch 2015). Only individuals can be required to pay reparations in the ICC, although states and others may voluntarily contribute to the Trust Fund for Victims. For the modern origin of 'full reparation' as the standard for remedies for international law violations generally, see Chorzow Factory (Merits), Judgment, PCIJ, Series A, No 17, p $47-48$ (1928).

This Report does not address whether the type and quantum of reparations in business-related human rights cases is or should be defined by public international law, by private international law, by national law, or by some other source of law. That is a matter left open by all of the UN documents.

2 UN Basic Principles (2005) preamble.

${ }^{3}$ Guiding Principles on Business and Human Rights, UN Doc. A/HRC/17/31, endorsed by Human Rights Committee Res 17/4 (2011) (Ruggie Principles (2011)).

${ }^{4}$ Ruggie Principles (2011) Principle 12.
} 
crimes should be is beyond the scope of this Report as well. ${ }^{5}$ The Ruggie Principles do recommend that states use 'hard law' of some sort, whether civil, criminal, or administrative, to back up the voluntary mechanisms that they hope will be generally accepted to prevent, monitor, and remedy human rights violations.

The Ruggie Principles document makes almost no reference to the 2005 UN Basic Principles. A document which brings them together is a Report prepared for the UN High Commissioner on Human Rights ('Zerk Report', named for author Jennifer Zerk). ${ }^{6}$ The Zerk Report was one of the preparatory documents for the 2016 Report of the UN High Commissioner for Human Rights, 'Improving accountability and access to remedy for victims of business-related human rights abuse', with its Annex 'Guidance to Improve corporate accountability and access to judicial remedy for business-related human rights abuse' (2016 Accountability/Guidance). ${ }^{7}$ As of February 2017, this remains a Report of the UN High Commissioner for Human Rights and has not been adopted by the Human Rights Committee or the General Assembly.

The 2016 Guidance is a soft law document aimed at states. ${ }^{8}$ It makes 'Recommendations' in the main Report and setting out 'Policy Objectives' in the Annex, but its tone is more forceful than that of the first two documents. Unlike the first two documents, it does not explicitly deny creating new international legal obligations of states. Like the earlier documents, the 2016 Guidance recommends that states use their 'hard law' to deal with human rights violations.

The United Nations is not the only body emphasizing reparations for crimes under international law with corporate involvement. As amicus curiae (friend of the court) in a famous United States Supreme Court case, Kiobel v. Royal Dutch Petroleum, ${ }^{9}$ the European Union stated that there is a

growing recognition in the international community that an effective remedy for repugnant crimes in violation of fundamental human rights includes, as an essential component, civil reparations to the victims. ${ }^{10}$

\footnotetext{
${ }^{5}$ Compare, eg, Rome Statute of the International Criminal Court (1998) arts 5-8 (setting out crimes in violation of international humanitarian law) with, eg, International Covenant on Civil and Political Rights (1966) (setting out individual human rights in the civil and political reaim).

${ }^{6}$ Jennifer Zerk, 'Corporate liability for gross human rights abuses: Towards a fairer and more effective system of domestic law remedies' (UN OHCHR (2014)) (Zerk Report (2014)).

7 UN High Commissioner for Human Rights, 'Improving accountability and access to remedy for victims of business-related human rights abuse' with Annex, 'Guidance to improve corporate accountability and access to judicial remedy for business-related human rights abuse,' UN Doc. A/HRC/32/19 (2016) (advance edited version) (Accountability/Guidance (2016)). There is an addendum to the Accountability/Guidance (2016), 'Improving accountability and access to remedy for victims of business-related human rights abuse: explanatory notes for guidance,' UN Doc. A/HRC/32/19/Add.1 (advance edited version) (Guidance Notes (2016)).
}

8 For the emphasis on states as the target audience, see Accountability/Guidance (2016) para 19.

9 US Kiobel v Royal Dutch Petroleum, 569 US (2013).

${ }^{10}$ US Kiobel, Brief of the European Commission on behalf of the European Union (2012) 17-18. 
The 2005 Basic Principles and Guidelines are addressed to whoever might cause a gross or serious violation - including 'a person, a legal person, or other entity.' ${ }^{11}$ The inclusion of legal person' here means that national law and national courts should enforce these types of remedies against corporations and other legal persons who are responsible for the violations. This is true whether the corporate crime involved is one of the core international crimes (i.e., international humanitarian law) or a treaty-based or other crime which invades an internationally-recognized human right.

The 2005 Basic Principles consider restitution, compensation, rehabilitation, satisfaction, and guarantees of non-repetition as possible means of reparation for these violations. The document sets out definitions which are worth quoting at length:

19. Restitution should, whenever possible, restore the victim to the original situation before the gross violations of international human rights law or serious violations of international humanitarian law occurred. Restitution includes, as appropriate: restoration of liberty, enjoyment of human rights, identity, family life and citizenship, return to one's place of residence, restoration of employment and return of property.

20. Compensation should be provided for any economically assessable damage, as appropriate and proportional to the gravity of the violation and the circumstances of each case, resulting from gross violations of international human rights law and serious violations of international humanitarian law, such as:
a) Physical or mental harm;
b) Lost opportunities, including employment, education and social benefits;
c) Material damages and loss of earnings, including loss of earning potential;
d) Moral damage;
e) Costs required for legal or expert assistance, medicine and medical services, and psychological and social services.

21. Rehabilitation should include medical and psychological care as well as legal and social services.

22. Satisfaction should include, where applicable, any or all of the following:

a) Effective measures aimed at the cessation of continuing violations;

b) Verification of the facts and full and public disclosure of the truth to the extent that such disclosure does not cause further harm or threaten the safety and interests of the victim, the victim's relatives, witnesses, or persons who have intervened to assist the victim or prevent the occurrence of further violations;

c) The search for the whereabouts of the disappeared, for the identities of thechildren abducted, and for the bodies of those killed, and assistance in the recovery, identification and reburial of the bodies in accordance with the expressed or presumed wish of the victims, or the cultural practices of the families and communities;

d) An official declaration or a judicial decision restoring the dignity, the reputation and the rights of the victim and of persons closely connected with the victim;

${ }_{11}$ UN Basic Principles (2005) art 15 (emphasis added). 
e) Public apology, including acknowledgement of the facts and acceptance of responsibility;

f) Judicial and administrative sanctions against persons liable for the violations;

g) Commemorations and tributes to the victims;

h) Inclusion of an accurate account of the violations that occurred in international human rights law and international humanitarian law training and in educational material at all levels.

23. Guarantees of non-repetition should include, where applicable, any or all of the following measures, which will also contribute to prevention:

a) Ensuring effective civilian control of military and security forces;

b) Ensuring that all civilian and military proceedings abide by international standards of due process, fairness and impartiality;

c) Strengthening the independence of the judiciary;

d) Protecting persons in the legal, medical and health-care professions, the media and other related professions, and human rights defenders;

e) Providing, on a priority and continued basis, human rights and international humanitarian law education to all sectors of society and training for law enforcement officials as well as military and security forces;

f) Promoting the observance of codes of conduct and ethical norms, in particular international standards, by public servants, including law enforcement, correctional, media, medical, psychological, social service and military personnel, as well as by economic enterprises;

g) Promoting mechanisms for preventing and monitoring social conflicts and their resolution;

h) Reviewing and reforming laws contributing to or allowing gross violations of international human rights law and serious violations of international humanitarian law. ${ }^{12}$

These remedies should not be considered exclusive. Nor will all of them be required in every case. What is important is that a corporation involved in a human rights violation which has disrupted the lives of many people, such as poisoning the drinking and irrigation water in a given place, may not simply be able to throw some money into a pot and leave.

The 2011 Ruggie Principles do not attempt to define or re-define these substantive remedies for business violations of human rights. Rather, they set forth courses of action that businesses ought to take to develop systems for preventing adverse human rights impacts from their activities, for monitoring whether such impacts are occurring, and for promptly remedying such impacts. The Ruggie Principles are neutral as to whether the remedies should come through criminal, administrative, and/or civil processes, so long as there is state law available to victims if voluntary remediation fails. ${ }^{13}$

12 UN Basic Principles (2005) arts 19-23.

13 See Ruggie Principles (2011) parts II (principles 11 \& 22) \& III. 
The 2016 Accountability/Guidance suggests states create both public (criminal and/or administrative) law sanctions and private (civil) law claims for corporate violations of international human rights abuses. Surprisingly, the 2016 Accountability/Guidance does not specifically address transnational enforceability of either civil or criminal judgments, though it does suggest greater cooperation between states in enforcement. ${ }^{14}$

This Report considers the jurisdictional prerequisites for effective reparation through the criminal process. It examines whether and how the law of jurisdiction can promote effective remedies for human rights violation through that process. The Ruggie Principles themselves are based on the idea that effective national laws on human rights are those that encourage business to monitor human rights effects and promote human rights voluntarily, including providing remedies before being forced to do so by courts. ${ }^{15}$

\subsection{Reparation and jurisdiction}

The relationship of restitution and reparation to decisions on corporate criminal liability and extraterritorial jurisdiction over corporations for international crimes is complex. It involves all three aspects of jurisdiction: prescriptive (legislative), adjudicative (judicial), and enforcement.

\subsubsection{Prescriptive and adjudicative jurisdiction: Defining crimes and sanctions}

In the literature, prescriptive and adjudicative jurisdiction over crime are generally seen as identical or very similar. For purposes of this discussion on effectiveness of reparations for crime, it will be useful to make a distinction.

Whether a state may define a crime where the acts or criminal results occurred outside the territory of a state and/or the perpetrator is a foreign national will be treated as a question of prescriptive jurisdiction. The essential question is whether the state has the authority to make law for the matter.

Whether a state has given its courts authority to impose a given sanction for a crime (e.g., restitution of property to victims) will be treated as a matter of jurisdiction to adjudicate. The question is whether a court acts within its sentencing powers in making such a judgment.

Technically, this distinction is a bit artificial. Nonetheless, it will be useful below in separating issues of crime (or cause of action) and sanction.

\subsubsection{Outline of the scheme of jurisdiction in international law}

This report assumes knowledge of the system of international and transnational jurisdiction over criminal law, which is discussed and developed in the each of the National Reports on this topic. The categories of prescriptive and adjudicative jurisdiction of this general system are:

\section{Territorial jurisdiction including}

\footnotetext{
${ }^{14}$ Accountability/Guidance (2016) Policy Objective 9.

${ }^{15}$ See Ruggie Principles (2011) esp. Operational Principles 27-31.
} 
a. Subjective territoriality, based on acts in the state claiming jurisdiction,

b. Objective territoriality, based on criminal results in the state, even if the acts occurred elsewhere), and

c. Ubiquity, based in either of the former;

2. Nationality (or active personality) jurisdiction, based on association of the actor with the state;

3. Protective jurisdiction, available only for certain crimes against the vital interests of state, no matter where committed or by whom;

4. Passive personality jurisdiction, based on the nationality of the victim (formerly controversial; now accepted at least for crimes committed against a person because of the person's nationality and terrorist crimes; used more generally in many civil law states); and,

5. Universal jurisdiction, based on the nature of the crime as one of great international concern (now accepted for piracy and the core international crimes of genocide, crimes against humanity, and war crimes, as well as torture; in the absence of treaty authorization, it is controversial at best for crimes which violate other human rights and for other crimes).

The National Reports also include discussion of a sixth base of jurisdiction, the representation principle or vicarious jurisdiction, also called subsidiary universal jurisdiction. This principle allows a state to exercise adjudicative jurisdiction over a crime using their own law if a non-national suspected of a crime committed elsewhere is found on its territory, but for some reason the person is not or cannot be extradited to a state with jurisdiction on one of the first four standard bases. This is generally a civil law form of jurisdiction, but has been accepted by other states in treaties defining certain crimes, including crimes involving human rights, in the form called 'aut dedere aut judicare (extradite or try) jurisdiction'. ${ }^{16}$

2.3 Obstacles to reparations in the international criminal courts and tribunals because of limitations of authority over subject matter and persons and limitation of resources

The first of the modern international criminal courts and tribunals were the UN Security Council-created Yugoslav (1993) and Rwanda (1994) Tribunals. They addressed the so-called 'core' international crimes of genocide, war crimes, and crimes against humanity. Concerning restitution, they began solely with authority to restore property wrongfully taken: 'the Trial Chambers may order the return of any property and proceeds acquired by

${ }^{16}$ Eg UN Convention against Torture (1984) art 5(2). 
criminal conduct, including by means of duress, to their rightful owners' ${ }^{17}$ Assistance with return of property was not explicitly required of states. ${ }^{18}$

The Rome Statute of the International Criminal Court (1998/eff. 2002) has a much wider-ranging scheme for reparations:

The Court may make an order directly against a convicted person specifying appropriate reparations to, or in respect of, victims, including restitution, compensation and rehabilitation. ${ }^{19}$

It may also order payment out of a Trust Fund for victims and their families. This fund may receive forfeited property and other assets from convicted persons and voluntary contributions from states and individuals. Finally, states parties to the ICC Statute are required to assist in:

The identification, tracing and freezing or seizure of proceeds, property and assets and instrumentalities of crimes for the purpose of eventual forfeiture, without prejudice to the rights of bona fide third parties ....$^{20}$

The ICC Statute also provides for a mechanism to get property or its proceeds transferred from the seizing state to the Court. ${ }^{21}$ The Bemba case, currently in the reparations phase, may yet produce some restitution or reparation for victims. ${ }^{22}$

These International Criminal Courts and Tribunals (ICCTs) limit their personal jurisdiction to natural persons, and exclude the possibility of charging corporations and other legal persons with crimes. Personal jurisdiction is usually conceptualized as an aspect of jurisdiction to adjudicate cases. However, in these courts, one might say that the lawmaking authorities have abdicated from the prescription of criminal law over corporations. ${ }^{23}$

\footnotetext{
${ }^{17}$ Statute of the International Criminal Tribunal for the Former Yugoslavia (1993) art 24(3) (ICTY Statute); accord, Statute of the International Criminal Tribunal for Rwanda (1994) art 23(3) (ICTR Statute). The Statute of the Special Court for Sierra Leone (2000) art 19(3) expanded the definition of what may be restored: the Court 'may order the forfeiture of the property, proceeds and any assets acquired unlawfully or by criminal conduct, and their return to their rightful owner or to the State of Sierra Leone.' Yet Charles Taylor, who was convicted of being an accessory to war crimes by selling weapons into the civil war in Sierra Leone, knowing they would be used for committing those crimes, was not ordered to forfeit the 'blood diamonds' that he received in payment or their proceeds.

${ }^{18}$ ICTY Statute, art 29; ICTR Statute, art 28.

${ }^{19}$ Rome Statute of the International Criminal Court (1998) arts 74(2), 75-76, 79, 93(1)(k) (ICC Statute).

${ }^{20}$ ICC Statute art 93(1)(k).

${ }^{21}$ ICC Statute art 109.

${ }^{22}$ Prosecutor $v$ Bemba, Sentencing Judgment, ICC 01/05-01/08 (2016) paras 82-84.

${ }^{23}$ That is, the UN Security Council (in the cases of the ad hoc Tribunals) and the states which adopted the ICC Statute (in the case of the ICC) chose not to define criminal law which the courts being created could apply to corporations. (This Report does not address the relationship between the international community as a whole as defining customary international criminal law on the one hand, and the Security Council or the group of states adopting the ICC Statute as defining law in the respective courts on the other. This is a major issue which can be explored elsewhere).
} 
There are three problems with the reparative system of ICCTs. First, the amounts collected from convicted persons have never been enough to come close to full restitution or compensation for the victims of mass atrocity. Most of those convicted of mass atrocity have not had resources for compensation.

Second, most violations of 'international human rights law' do not fall within the mandate of these international criminal courts and tribunals, but are covered by various treaties or are coming to be recognized in other sources of international law. The crimes covered by the ICCTs are generally conceptualized as violations of 'international humanitarian law', ${ }^{24}$ the law of armed conflict. International human rights law is a law covering human rights during peacetime.

Third, many violations of human rights (broadly defined), including unfair treatment of workers or environmental degradation, involve economic activity of multinational enterprises, whose wealth is seldom held by a single individual. These enterprises often benefit from such violations. As a result, many have turned to corporations and other business entities which participate in human rights violation as a just, and more likely, source of reparations for victims.

\subsection{The Ruggie Principles and reparations}

The Ruggie Principles are designed to fill the gaps identified at the end of the previous section. The Ruggie Principles recommend corporate responsibility to remedy any human rights violations which occur. In particular, the principles require both that states make judicial remedies available for victims of human rights violations, and that states and businesses provide non-judicial avenues for remediation as well. ${ }^{25}$

One can see this responsibility to remedy as arising naturally out of the 2005 Basic Principles on reparations. Perhaps the big difference here is that the Ruggie Principles do not require 'gross' violations. ${ }^{26}$ The nature of many human rights and international humanitarian law violations, then and now, suggest that corporations are, or ought to be, responsible for them in appropriate situations, even if only a few individuals are affected. Indeed, the systematic approach of the Ruggie Principles aims to prevent human rights violations through local action, and if that is not possible, to remedy them quickly, before they become widespread.

The Ruggie Principles do not directly speak to whether or not the judicial remedies for human rights violations should include criminal penalties for corporate entities. This is not surprising given that the Principles seek participation from states which have very different attitudes towards applying criminal sanctions to legal persons. This recognition of different legal systems is consistent with the modern treaty approach to requiring corporate liability

\footnotetext{
${ }^{24}$ See, eg, the Preambies to the Statutes of the ICTY, ICTR, \& ICC.

25 Ruggie Principles (2011) parts II (principles 11 \& 22) \& III.

26 This Report does not address the emphasis of the Ruggie Principles on prevention and deterrence of violations.
} 
for treaty violations, but allowing the liability to take a form, administrative, civil, or criminal, consistent with the legal principles of each country which is party to the treaty. ${ }^{27}$

The discussion in this Report focuses on jurisdictional issues arising in criminal cases. It will raise the question whether addressing human rights violations non-criminally might ameliorate some jurisdictional problems.

\subsection{Multinational enterprises and human rights violations: a scenario}

The organization of business enterprises for purposes of operating across borders is varied. It is not possible even to specify all of the possible options. For purposes of simplicity, this Report will discuss a common scenario: A multinational business, corporation A, is legally organized and headquartered in state A (often referred to in the literature as the 'home state' of the multinational enterprise). For a combination of business and legal reasons, it forms a subsidiary, corporation B, legally organized, headquartered, and doing substantially all its business in state $\mathrm{B}$. Corporation B's activities are basically controlled by corporation $\mathrm{A}$. The shareholders of corporation $B$ are corporation $A$ and some local investors who are nationals of state $B$. Much of corporation B's profits are repatriated to state $A$, and some of corporation B's assets are held in state $C$.

In this imperfect world, one can imagine that the operations of corporation B cause violations of human rights of persons in state $B$. These violations might include poisoning the water in a town where corporation B has a factory, employing slave labor, killing the publishers of a newspaper opposing the activities of corporations $A$ and $B$, allowing its facilities to be used for torture of political opponents of the governments of $A$ and/or $B$, selling guns to militias who will use them to massacre civilians, and committing any other sort of evil that might be considered a violation of human rights (broadly construed). This list of examples was drawn up to include violations committed at the behest of the state as well as by the corporation alone; violations of rules which are part of international humanitarian law (the law of armed conflict) and of general human rights law; violations of individual civil liberties and of what are sometimes called collective rights (e.g., to a healthy environment).

One can also imagine different levels of participation of corporation $\mathrm{A}$ in the crimes: its high officers or low-level employees may have: directed and/or participated in the violations, expressly condoned the violations, known of the violations and tacitly condoned them, known of the violations but did nothing, suspected the violations without investigating to find out more, knew nothing but should have known about the violations, etc. Corporation $A^{\prime}$ 's personnel may have directed corporation $B^{\prime}$ s personnel to maximize profits at all costs, may have demonstrated that sort of attitude without directly saying so, may have refused or failed to set up the factory to operate safely or to train corporation B's personnel, may have given no direction on these issues, or may have encouraged safe practices. Corporation B's personnel may have actively and voluntarily participated in the abuses, or objected to

\footnotetext{
${ }^{27}$ See UN International Convention on the Suppression of the Financing of Terrorism (1999) art 5 (liability may be criminal, civil or administrative); UN Convention against Transnational Organized Crime (2000) art 10 (similar); UN Convention against Corruption (2003) art 26 (similar).
} 
them, or may have blown the whistle on them. These levels of participation in human rights violations were chosen to illustrate the various ways of attributing individual conduct to corporations shown in the National Reports.

\section{International law jurisdictional issues concerning reparations for corporate crimes: The traditional rules}

As we have said, the legal remediation of a wrong by transnational corporate actors depends on all three aspects of legal power: prescription, adjudication, and enforcement. The National Reporters have said a great deal about jurisdiction over corporations for international crimes, both in their own countries and comparatively. This Report will focus on specific jurisdictional issues which must be faced if reparation for transnational wrongdoing concerning human rights treaty crimes and core international crimes is to be a realistic objective of corporate criminal liability.

When we talk about traditional rules of jurisdiction, we are discussing law which developed over centuries, taking its present form largely in the nineteenth and early twentieth centuries. Criminalization of corporate activities is in general a more recent phenomenon. Even today there are many states which, as a matter of principle, do not hold corporations criminally liable for their wrongs.

By the third quarter of the twentieth century many states, at least in the common law world, had introduced the concept of corporate criminal liability through statute or caselaw. Roughly by the beginning of the twenty-first century, treaties requiring states to criminalize certain activities also began to require that corporations and other legal or artificial persons be held accountable for the same set of acts either criminally, civilly, or administratively. ${ }^{28}$

\subsection{Corporate crime and substantive criminal law related to jurisdiction}

The National Reporters have shown that two sets of general principles of substantive law are important to understanding when jurisdiction to prescribe can really be effective. One is the substantive criminal law rules on accomplice liability and related doctrines concerning when a person is criminally liable for the acts of another. The other is the doctrine, originating in non-criminal law, of when a corporation (or other natural or artificial person) can be liable for acts of an agent or another person with a relationship to it. Depending on the law of a state, either or both of these may be vital to determining whether and when a parent corporation can be prosecuted for overseas acts of its subsidiary or other related person or entity. ${ }^{29}$

There are also some important doctrines which are specific to corporate responsibility. Some National Reports also show specific national law limits on corporate criminal liability. Some

\footnotetext{
${ }^{28} \mathrm{Eg}$, UN Convention against Corruption (2004) art. 26(2).

${ }^{29}$ See Austria Report sec. 1 (last three paragraphs of Introduction, on how principles of liability for acts of others have special characteristics in context of corporate parents and subsidiaries); Finland Report sec. 2.1.1 (showing relevance of Finland Criminal Code chap. 1, sec. 10(3) on complicity liability of corporations); Italy Report, sec. 1.1 ('Doctrinal basis' portion on 'failing to prevent' crime as basis for liability); Switzerland Report, sec. 2.1.2 (setting out a complex set of requirements for corporate liability).
} 
states limit this liability to certain offenses. ${ }^{30}$ Some states subject corporations only to civil or administrative liability. Some national law shows that who is involved in a corporate decision is vital to determining corporate liability. ${ }^{31}$

Any of these national rules of law may, in the context of the law of a given state, limit reparative responsibility on the parent corporation through the criminal law. As the Australia National Report says, corporate crime rules may contain 'specific departures from the general liability rules . . ${ }^{32}$ This Report will discuss these doctrines of substantive criminal law to the extent necessary to show the relationship of a decision to exercise jurisdiction (of any kind) over the parent company to the ability to repair the wrong done.

\subsection{Prescriptive jurisdiction over crime by corporations}

Creation of a law of corporate crime requires authority in an entity - whether a state or a transnational or global entity - to make law which regulates or forbids certain conduct by the corporation or those acting for it. ${ }^{33}$ To satisfy the principle of legality, that authority must have been exercised in advance of the conduct in question. That is, there must have been an exercise of legislative jurisdiction applicable to the specific event and the individual or legal entity accused. The exercise of legislative jurisdiction must also authorize penalties which either explicitly or implicitly provide for the possibility of reparative sanctions. ${ }^{34}$

In general, international law permits states to exercise prescriptive jurisdiction over corporations, including the authority to make them liable for crimes. There are, however, a few more issues concerning this authority than there are in the case of crime by natural persons. The most important of them involve the ability of a state to legislate for an enterprise which is in legal terms divided into several artificial persons, such as a corporate parent, subsidiaries or otherwise controlled entities, and/or partners in a joint venture.

Under international law, a state has prescriptive jurisdiction over corporations and other artificial legal entities that have been created under its law. It also has prescriptive jurisdiction over a corporation if the state is its 'principal place of business', its 'head office', or its 'siège sociale' (depending on the legal conception used by the particular state involved),

\footnotetext{
${ }^{30}$ Australia Report, sec. 3 (on covered core and treaty crimes); Italy Report sec. 1.1 ('Scope of corporate liability' subsection on treaty rather than core crimes being covered).

${ }^{31}$ Finland Report, sec. 1.1.1 (only acts of certain persons within the corporation invoke corporate responsibility); Italy Report, sec. 1.1 ('Doctrinal basis' portion on who may cause corporation to be liable).

${ }^{32}$ Australia National Report, sec. 2.

${ }^{33}$ The notion of a 'transnational or global entity' includes the community of states and other actors who contribute the construction of customary international law and general principles of law. Cf, eg, International Covenant on Civil and Political Rights [ICCPR] (1966) art 15(2) (general principles of law as a source of international criminal law).

${ }^{34}$ See, eg, ICCPR (1966) art 15(1); European Convention on Human Rights and Fundamental Freedoms (1950) art 7 (ECHR); American Convention on Human Rights (1967) arts 7-9; African Charter of Human and Peoples Rights (1981) art 7(2); [Revised] Arab Charter on Human Rights (2004) art 15. See Kenneth S. Gallant, The Principle of Legality in International and Comparative Criminal Law (Cambridge Univ Press 2009) Ch 7 (for legality as a matter of customary international law, and perhaps jus cogens), conclusion (for relationship of legality to jurisdiction); Per Ole Träskman, 'Should We Take the Requirement of Double Criminality Seriously?' in Nils Jareborg, Double Criminality (Iustus Förlag 1989) 135, 149ff (for relationship of legality to jurisdiction).
} 
at least as to the corporation's dealings with third parties. This 'national character' authority over corporations is the companion of nationality jurisdiction over natural persons.

A few states claim jurisdiction over business enterprises as though they were artificial persons even when, under national law, the enterprises do not qualify as true artificial persons. ${ }^{35}$ It is not clear whether any transnational entities have been branded as artificial persons with the national character of one particular state under any of these laws. An effort to do so might raise interesting problems but they will not be explored here.

A state has prescriptive jurisdiction over a corporation's territorial acts. A state has prescriptive jurisdiction over a corporation whose outside acts cause criminal results on its territory, at least when the results are direct, substantial, and foreseeable. ${ }^{36}$ These are analogues of subjective and objective territorial jurisdiction (which together make up the doctrine of ubiquity) over natural persons.

There is controversy around the exact parameters of the principles applied to corporations. Naturally, a major issue arises over whether and when an action by persons associated with the parent corporation on the territory of the parent's home state may be said to have 'caused' a criminal result occurring in the host state. For the moment though, this description of the principles is sufficient.

A state need not admit a foreign corporation to do business on its territory. It may require that a foreign corporation or business enterprise which wishes to operate on its territory meet certain conditions. Commonly, the foreign corporation must form a local subsidiary. This subsidiary is usually an artificial or legal person under the law where it is formed. There may also be local ownership requirements for the subsidiary. These requirements may be seen as having two justifications. One is to clearly subject the actions of the multinational enterprise in the state to the law of the state by ensuring that there is an entity in the state which can be held responsible. The other is to ensure that a share of the profits of the actions of the enterprise inure to persons in the state. For the purposes of this Report, the first justification is key. (Even where these requirements do not exist, multinational enterprises may wish to create local or regional subsidiaries and to have local investors. These will often be vital to understanding local, national, and regional business and consumer culture.)

The local subsidiary is responsible to the law of its state. There can be no doubt about this. The local subsidiary is usually the means by which the multinational enterprise acts there. Depending on the local law, this state may also be required to own the assets used for these activities. If there is no such requirement of ownership, the enterprise may use assets owned

\footnotetext{
${ }^{35}$ See Netheriands Penal Code art 51(3) (for the purpose of criminal law, 'equal status as a legal person applies to a company without legal personality, a partnership, a firm of ship owners, and a separate capital sum assembled for a special purpose'); Italy Report, sec 1.1, discussing Italy Legislative Decree 8 June 2001, no 231, $\sec 1$.

${ }^{36}$ See, eg, EC Wood Pulp Cases (A. Ahlstr6m Osakeyhti6 v European Commission), Common Mkt Rep (CCH) 1 14,491 (Ct of Justice of the European Community, 1988); 15 USC sec 6A. (US Foreign Trade Antitrust Improvements Act); US Hartford Fire Ins Co v California, 509 US 764, 766 (1994) ('substantial and intended'). These are competition cases and statutes, not human rights matters.
} 
by a different entity incorporated elsewhere. This, as we will see, may make it more difficult to obtain a remedy for wrongs committed in the state.

\subsubsection{Separate personhood of parent and subsidiary corporations}

International law recognizes a subsidiary corporation created pursuant to a state's law as a legal person separate from a parent corporation created pursuant to a different state's law. This is true even if the parent corporation is the sole owner of the shares of the subsidiary. In general, international law recognizes a corporation created pursuant to a state's law as a legal or artificial person separate from its owners from other states, regardless of whether those owners are natural persons or legal persons. ${ }^{37}$ National law usually recognizes the separate personhood of corporations and their owners, regardless of the nationality of either.

This has consequences for the international law of prescriptive and adjudicative jurisdiction over corporations. The consequences can be outlined in the example above in section $I(E)$ : State A is the 'home state' of a corporation A which does business transnationally. State B is the 'host state' of some of corporation A's business interests. These interests all involve property owned by and activities of corporation B, a subsidiary of corporation A. Corporation $B$, though, is organized under the laws of state $B$.

In the jurisdictional tradition, state A clearly has jurisdiction to prescribe law for the territorial activities of corporation A through territorial jurisdiction. It also has jurisdiction to prescribe law for the extraterritorial activities of corporation $A$, as the corporation has state $A^{\prime}$ 's national character. However, corporation $B$ has the national character of state $B$. Therefore, state A cannot simply exercise jurisdiction to prescribe law for the activities of corporation $B$. Those activities are not carried out on the territory of state A, nor are they carried out by a national of state $A$. This is the reason that the separation of legal persons is so important to issues of protecting natural persons from human rights violations.

The core international crimes are generally accepted as being subject to universal jurisdiction. That is, any state may prosecute genocide, crimes against humanity, and war crimes, no matter where the crimes were committed, who allegedly committed them, and who the victims were. Torture is likely in this group as well, ${ }^{38}$ as are slavery and slave trading. Piracy is the original universal jurisdiction crime, though it is not historically treated as a human rights issue.

Other crimes which are recognized (or are coming to be recognized) in international law as human rights violations and which may be committed by business entities are systematic, gross violations of fair labor standards or degradation of the environment at and around a factory. These are not yet recognized by customary international law as giving rise to universal criminal jurisdiction. As a result, these crimes are limited to the forms of jurisdiction authorized in the relevant treaties or in customary international law, particularly territorial and nationality jurisdiction.

\footnotetext{
${ }^{37}$ See ICJ Barcelona Traction (Belgium v Spain), [1970] ICJ Rep 3.

${ }^{38}$ See Case concerning obligation to Extradite or Try (Belgium v Senegal) [2012] ICJ Rep 422.
} 
The questions, then, are as follows: To what extent may a state with prescriptive jurisdiction over the parent corporation also exercise such jurisdiction over a subsidiary or other entity associated to the parent formed and operated in another state? To what extent may a state with prescriptive jurisdiction over a subsidiary or other associated entity exercise such jurisdiction over the parent corporation? One way the debate is framed is whether to treat an entire commercial enterprise as a single unit. As F.A. Mann pointed out over thirty years ago, this is desirable in principle, but not always achievable given the current state of international and national law, because the legal persons making up the enterprise are treated as separate. ${ }^{39}$

\subsubsection{Application of traditional rules: objective territoriality}

One can see from these principles that it is possible for both the home states of multinational businesses and the host states of their subsidiaries, branches, or other related entities to use criminal law as a tool against international human rights and international humanitarian law violations. In the example from section 1.5 above, the home state of corporation $\mathrm{A}$, state A, may legislate to prohibit acts of the corporation which cause violations of human rights, even if those violations occur elsewhere, in state $B$ (subjective territorial jurisdiction over the corporation. State A has authority to make such laws, even if the acts of its agents which caused the violations were performed in state $B$ - or indeed anywhere else (jurisdiction over a corporation with its national character).

State $B$ has jurisdiction to legislate over acts of corporation B, a subsidiary of corporation $A$, which cause harm in its own territory. If the acts occurred in state $B$, there is subjective and objective territorial jurisdiction; if they occurred elsewhere, there is objective territorial jurisdiction; in either case, there is also jurisdiction over the corporation with the national character of state B.

State $B$ may also have jurisdiction to legislate for corporation $A$ as well. If acts of corporation $A$ are committed on the territory of state $B$, as where it has a branch office, jurisdictional authority is clear. Even if no acts of corporation $A$ have been committed on the territory of state $B$, there may still be legislative jurisdiction if the acts resulted in human rights violations in state $\mathrm{B}$, on the basis of objective territoriality. We see from the National Reports that objective territoriality is widely practiced. There are very few states which reject it, and they generally do not appear to object diplomatically when other states use it. New developments, discussed in part IV, have only strengthen the position that a state has prescriptive jurisdiction over a corporation whose acts abroad cause a crime in the prosecuting state.

\footnotetext{
${ }^{39}$ See FA Mann, The Doctrine of International Jurisdiction Reconsidered after Twenty Years, Recueil des cours vo 186, pp 1, 54 (1984). For an example of national law which does not allow for prosecution of the entir enterprise or concern, see Austria Report sec. 2.1.1.a.
} 


\subsubsection{Criminal responsibility of individuals not impaired by corporate criminal liability}

In most states, one is criminally responsible for one's own acts, even if they were done on behalf of a corporation. Corporate criminal liability does not remove individual liability, either traditionally or today. ${ }^{40}$

A state has jurisdiction to make law for its individual nationals who are outside its borders, as well as for territorial acts. For example, in the scenario described in section 1.5 above, assume that a Director of subsidiary corporation B, who works in state B, is also a national of state A. State A may exercise prescriptive jurisdiction for the Director on the basis of nationality jurisdiction. State B may exercise prescriptive jurisdiction over the Director on the basis of territorial jurisdiction. As a result, if the Director orders, participates in, or abets a crime in state $\mathrm{B}$, the Director may be criminally responsible to either state, if the national law of each state makes her so. ${ }^{41}$

\subsection{Adjudicative jurisdiction: Trial and sanctions}

In terms of adjudicative jurisdiction, there must be a court or similar entity with authority to adjudicate the charge and to impose a judgment with a reparative element. In general, for criminal law, adjudicative and prescriptive jurisdiction are the same. This follows from the principle that a state will only apply its own criminal law in its courts. Thus, if it cannot adjudicate cases over which it has prescriptive jurisdiction, it is effectively deprived of some authority to define crime. Corporate criminal liability raises new problems of adjudicative jurisdiction.

First, the international law of adjudicative jurisdiction over businesses includes at least one limitation from the law of corporate personhood. State law must recognize that when a transnational enterprise has created incorporated units in different states (whether or not the units are parent and subsidiary or subsidiaries), the units are different legal persons, with different national characters. The legal separation is normally true under national law if the units are incorporated in the same state. In a single state, however, that state may change this doctrine of corporate law. It may ignore the distinction if it wishes (it may 'pierce the corporate veil') for many purposes, including protection of victims of law violations. In the multinational situation, however, the distinction of corporations as persons with distinct nationalities may not be overridden simply by national fiat. ${ }^{42}$ This enforced separation of artificial persons has been critical to shaping the substantive law of corporate human rights crime.

\footnotetext{
${ }^{40}$ See generally Charles Doyle, Corporate Criminal Liability: An Overview of Federal Law, (US Congressional Research Paper 2013) 5.

${ }^{41} \mathrm{~A}$ few states, especially the United States and United Kingdom, have attempted to take the idea of a 'national person' further, especially in corruption cases. The United States has attempted to maintain the national character of exported goods and technology (eg in the Siberian Pipeline conflict of the 1980s and the more recent enforcement of an embargo on nuclear technology going to Iran). This Report does not deal with these issues.

${ }^{42}$ See ICJ Barcelona Traction (1970).
} 
Specifically, separation of artificial persons created by different states in international law limits penalties against business enterprises. The state of incorporation has exclusive jurisdiction over matters of existence and dissolution of an entity incorporated there. As a result, options for sanctions on corporations involving their existence or internal organization may not be available to states other than the state of the incorporation. Another state, either where the corporation acted or where its acts caused criminal results, may have sanctions involving loss of the right to do business in the state - but cannot dissolve the corporation.

Second, many states include limitations on the amount of monetary sanctions in their schemes for exercising adjudicative jurisdiction over corporations. These sanctions, while substantial, may be inadequate for remedying major wrongs implicating human rights. ${ }^{43}$

Third, many states still apply criminal law only to natural persons. In such states, remedies against corporations and legal persons for human rights abuses will be either civil or administrative. The Germany and Italy Reports present good examples of law for corporate administrative liability for what would otherwise be criminal actions. Each of those states has committed its law to addressing the problem of transnational corporate crime in the human rights context, but each of them applies non-criminal or quasi-criminal administrative sanctions to corporations, instead of true criminal law.

Fourth, countries vary greatly in their treatment of victims in criminal cases. In some civil law countries, such as France, a crime victim can become a civil party to the action and obtain a reparative judgment against a criminal, which for some purposes may be treated as a civil judgment. ${ }^{44}$ In most common law countries, a criminal case is between the state as prosecutor and the defendant. Criminal penalties in some countries may include orders of restitution or other remedy from the defendant to the victim. There are many varieties of these systems. All of these systems are acceptable in customary international law. However, as we will see, they may have different consequences for enforceability of remedies for transnational crimes.

Fifth, where a state attempts to prosecute a foreign corporation on the basis of objective territorial jurisdiction, it may have trouble bringing the corporation into court. Unlike individuals, corporations cannot be 'extradited' from one state to another. The situation is most likely to arise where corporation $A$, with the national character of state $A$, allegedly commits an act in state $A$ which causes a criminal result in state $B$. Assume that state $A$ does not technically 'do business' in state $B$, and thus has not registered there or submitted itself to jurisdiction of $B$ 's courts. It will be very difficult to force corporation $A$ into the courts of state $B$ to answer the charge. Some states exercise adjudicative jurisdiction in absentia in criminal cases. Any judgment on such a basis, however, may not be recognized by other states for that reason. Because states only enforce their own criminal laws, state $B$ cannot do

${ }_{43}$ See eg, Finland Report sec 1.1.1 (850,000 Euros maximum); Switzerland Report sec 1.1.3 (maximum fine CHF 5,000,000, but describing at least one negotiated settlement beyond this amount, with CHF 36,400,000 going for 'compensation to victims'); see Zerk Report (2014) 85-87.

${ }^{44}$ See Zerk Report (2014) 77 and passim. 
in this criminal case what a private plaintiff could do in a civil case: go into the courts of state $\mathrm{A}$ to bring corporation $\mathrm{A}$ to book there.

\subsection{Enforcement jurisdiction}

Through and through, the Ruggie Principles aim at voluntary, systematic, proactive human rights monitoring and compliance by business entities. However, they recognize that such compliance depends, in large part, on the existence of hard law and state-based legal mechanisms for enforcing compliance. ${ }^{45}$ The 2016 Accountability/Guidance is aimed specifically at state entities. ${ }^{46}$ Yet enforcement authority may present the greatest challenge to achieving reparation through corporate criminal liability.

First, enforcement jurisdiction - including the authority to seize property - is entirely territorial, whether the matter is civil, administrative, or criminal. It may not be exercised on the territory of another state without permission. This is a rule of public international law that all states recognize. The state in which corporate assets are held thus has power over the enforcement of judgments against the property, even if it is not the state of the corporation's national character or the state where the corporation acted or caused harm.

Second, traditionally states will not enforce the penal law or penal judgments of other states. ${ }^{47}$ This rule is generally followed by states under their own laws, but it is not compelled by public international law. ${ }^{48}$ States may need to adjust national law concerning recognition of penal judgments to make criminal jurisdiction over corporations a useful tool for promoting human rights reparations. Both bilateral and multilateral treaty-making may help make this adjustment possible.

Where these traditional rules apply, a state in which persons have been injured by a multinational business' crime may find itself in an awkward position. The state may be able to charge and convict the local subsidiary of the crime. The sentence may include forfeiture of profits gained through the crime and fines for other compensation. Yet the state may find that it cannot seize the property required for reparations because it is held elsewhere or may be owned by another legal entity of the enterprise. In our example from section 1.5, assume corporation B in host state B has most of its assets held in state C. Assume the corporation has been criminally convicted in state $B$ with a penalty of forfeiture of assets for reparations purposes. Assume also that the corporate assets held in state $B$ are insufficient to meet the

\footnotetext{
45 See Ruggie Principles (2011) principles 25, 26 (court and non-court state remedies for human rights violations by business). The Ruggie Principles are designed to produce exemplars of rule of law as set forth by H.L.A. Hart, The Concept of Law (3rd ed, 2012; orig 1961): general voluntary compliance with mandatory rules, backed up by unbiased judgment and enforcement power.

${ }^{46}$ Accountability/Guidance (2016) para 19.

${ }^{47}$ See M Cherif Bassiouni, 'Introduction to Recognition of Foreign Penal Judgments,' in M Cherif Bassiouni, ed, International Criminal Law, vol. II (Multilateral and Bilateral Enforcement) (3rd ed, 2008) 507, going back to US The Antelope, 23 US 66 (1825) ('The courts of no country execute the penal laws of another...').

${ }^{48}$ See Ralf Michaels 'Recognition and Enforcement of Foreign Judgments' in Max Planck Encyclopedia of Public International Law (2009) <www.mpepil.com>.
} 
reparation requirement. Under the traditional rules, state $C$ would not execute the criminal judgment by seizing corporation B's assets there.

Where the traditional rules apply, legal characterization of a matter in the adjudicating state may also make a great difference to foreign enforceability. Given a state in which a victim of human rights violations brings a civil case against a corporation, other states will recognize and enforce a money judgment from that case on the same basis as other civil money judgments. A similar result may occur given a state in which victims are 'civil parties' in proceedings connected to criminal prosecutions. ${ }^{49}$ In states where judgments in criminal cases are characterized as wholly criminal, such foreign enforceability will not be directly available without modification of national law.

Conversely, a prosecution may be against the parent corporation in its home state, for crimes committed elsewhere in the world by it or its subsidiaries at its direction or with its complicity. Devising a remedy which restores the injured persons and communities may require a highly place- and context- specific negotiation in the place where the injury occurred. It may also require a complex scheme of implementation (for example, environmental restoration). Under the traditional rules, neither of these can be done on the territory of victims' state as part of the criminal matter without permission of the state. Such schemes of implementation may often need some form of regulatory approval by the host state, no matter the form of the judgment as civil or criminal.

Executing judgments for restitution and reparation for human rights violations by corporation may sometimes be easier if the judgment is civil rather than criminal. It should not be assumed that judgments against multinational parent corporations will always come from courts in states where the corporation has a great deal of assets, nor that they will always make payments voluntarily.

So long as a foreign judgment can fairly be called both civil in form and purely compensatory to victims (i.e., the judgment does not contain sums denoted or obviously intended as punishments unconnected to reparations), states will usually apply their private international law rules on recognition and enforcement of foreign judgments. ${ }^{50}$

That a case involves violation of human rights should not be a negative factor in determining whether to enforce a judgment. States should not reject foreign judgments for violations of human rights on the ground that they are based on advancing a state interest of the issuing state. ${ }^{51}$ In these cases, human rights are interests of all states, and therefore should be treated

${ }^{49}$ Cf. Treaty between Great Britain and France, Reciprocal Enforcement of Judgements (1934) art. 2(2); EU Regulation No. 2015/2012 on jurisdiction and the recognition and enforcement of judgments in civil and commercial matters (2012) ('Recast Brussels I') arts 2(a), 7(3), 39, 45, 46; ECJ Case C-52314, Annnemingsbedrijf Aertssen NV v VSB Machineverhuur BV , ECJ (3rd Chamber), paras 31-36 (2015)..

50 See generally Ralf Michaels, 'Recognition and Enforcement of Foreign Judgments' in Max Planck Encyclopedia of Public International Law (2009) <www.mpepil.com>.

51 Some states may treat administrative orders or judgments of other states as unenforceable because they promote the governmental interest or public law of the issuing state. Cf. Michaels (2009) para 3; Directive 2012/29/EU establishing minimum standards on the rights, support and protection of victims of crime (2012) art 1(1).This issue will not be addressed in this paper, except to point out progress made by treaty in 
across borders at least as respectfully as any other judgment of the rendering state would be treated in private international law.

Responding to problems of restitution and reparations caused by international law

4.1 Substantive law doctrines on liability of corporations for their own acts and for acts of subsidiaries or parents

The separate personhood of parent and subsidiary corporations creates difficulties in remedying human rights violations by business enterprises. The home states of parent corporations need to develop rules of law to determine when the parent may become liable for acts of its foreign subsidiaries or foreign partners. Similarly, the host states of subsidiaries of foreign parents must adopt some legal mechanism for using their own law to obtain reparation for and prevent repetition of human rights abuses in the host state ordered or tolerated by the outside parent. Most commonly, states use substantive criminal law doctrines of responsibility of one person for acts of another to address the issue of separate corporate personhoods. They also use agency-type concepts to define who has acted or may act for the corporation for purposes of criminal liability.

\subsubsection{Whose acts engage corporate responsibility?}

In some places, in order to engage corporate responsibility, some wrongful act must have been committed by a high official of a corporation, whether a director, officer, or similar person with responsibility for corporate policy or decision-making. As the Austria Report states, the substantive wrongful act may have been done by a lower ranking officer or employee because of a failure of a high official to take necessary measures to prevent the offense. ${ }^{52}$ The idea of limiting corporate crime to those with some involvement of higher management is to make sure that attribution liability of the corporation is really fair, given the possible adverse consequences for various stakeholders, such as shareholders and workers.

The Australia Report notes that a corporation is objectively liable if the wrongful acts or omissions were committed by an employee, agent, or officer, who was acting within the actual or apparent scope of his/her employment or authority. ${ }^{53}$ The United States Report notes a similar standard, and shows that respondeat superior - the doctrine that a principal is liable for the acts of its agent done within the scope of actual or apparent authority - is applicable in US federal criminal cases. ${ }^{54}$ Corporate criminal responsibility in these two

\footnotetext{
eliminating this obstacle to recognition and enforcement of foreign judgments. See Michaels (2009) para 16, citing Bustamante Code [Private International Law treaty] (1928) arts 423-37.

${ }^{52}$ See Austria Report, based on National Reporters' reading of statutes and doctrine.

${ }^{53}$ Australia Report sec. 3.2, citing Australia Criminal Code 1995 (Cth), sec 12.2.

${ }^{54}$ United States Report sec 1.1.1. The Zerk Report (2014) 69 argues the definition of genocide, war crimes, and torture in US law 'seems geared toward individual defendants.' This, however, is true of the definition of most crimes and causes of action, and the rules of attribution set forth in the US Report. and the documentation in the Report demonstrate that the US Report is correct.
} 
common law countries is, in theory, far broader than in states whose codes which limit engagement of corporate responsibility to acts by high officials of the corporation.

Respondeat superior liability is often called 'vicarious' liability of the corporation, because there may have been no official act of the corporation approving what the agent has done. Because all 'corporate acts' are eventually the acts of individuals with separate legal personalities, however, one might reasonably call all corporate criminal liability 'vicarious' in one sense or another.

\subsubsection{What crimes can engage corporate responsibility?}

Some states have rather broad statutes effectively making corporations liable for violating any criminal law. ${ }^{55}$ Some of these states require that an act must either benefit the corporation, be done to benefit the corporation, or violate the corporation's obligations, or any of these. ${ }^{56}$

The Australia Report notes that the national Parliament has criminalized acts constituting both core international crimes and many treaty-based human rights crimes. In principle, Australian corporations are liable for any violation of Australian criminal law. As noted above, they can be performed ay any employee, agent, or officer. The Australia Report notes that Australian law has a broad provision which defines mens rea terms of general criminal law as being applicable to corporations. The United States Report shows similar rules. ${ }^{57}$

Some states have specific code provisions invoking corporate liability for certain crimes. ${ }^{58}$ This is generally a more limited form of liability we see in the common law Reports.

\subsubsection{Secondary liability and reparations}

In many cases, the liability of a parent corporation from a developed state will be as a secondary party to a crime committed by personnel of a subsidiary corporation in a developing state. The personnel of the parent corporation may also be liable individually. For this reason, doctrines of accomplice liability, conspiracy liability, and other forms of joint criminality may be important to obtaining redress from a party which bears responsibility for the crime. There is a trend to have some form of this so-called secondary responsibility in corporate criminal cases, growing out of the ideas of secondary responsibility in general criminal law..$^{59}$

The secondary liability idea may be applied in situations other than the parent/subsidiary corporate relationship. The idea arose from the association of independent people acting to

\footnotetext{
${ }^{55}$ Australia Report, Corporate Criminal Liability Rules; Austria Report, sec B.I.1.a.

56 See Brazil Report sec B.I.1.a; Austria Report B.I.1.a;

${ }^{57}$ United States Report sec 1.1.1 (concerning 'imputed intent', the Report covers intent, knowledge, and "willful blindness" by agents, as well as conspiracies by employees, being attributed to corporations).

${ }^{58}$ See Brazil Report sec 1.1.1 (Brazil Const. arts. 173 \& 225 authorize creation of crimes against economic and financial order, citizens' monies, and the environment, whether committed by natural or legal persons).

${ }^{59}$ Zerk Report secs 2.1.2, 2.1.3 ; see also Austria Report sec. 2.1.1.a.
} 
commit a crime. It applies to corporations which aid individuals or government agencies to commit human rights crimes.

\subsubsection{The 'supply chain' problem}

The Ruggie Principles urge states and businesses to avoid human rights abuses up and down 'the supply chain' - i.e., whether or not the business entities with which they deal are either formally or substantially part of a multinational enterprise. The KiK/Bangladesh factory fire presents a good example of this problem. The Netherlands multinational retailer $\mathrm{KiK}$ regularly purchased clothing from a business in Bangladesh whose factory caught fire, killing over 200 employees. By any reasonable standards, the working conditions at the factory were extremely unsafe, in a way that was likely to result in such a disaster. The Ruggie Principles urge businesses to exercise 'human rights due diligence' concerning their suppliers, so that they can convince those suppliers to meet minimum standards, or switch to suppliers who do. ${ }^{60}$ The Ruggie Principles are more ambivalent on whether this should be a legal requirement for businesses to comply with. The overall thrust of the 'black letter' of the principles is that it should be. However, the Commentary states:

Where adverse impacts have occurred that the business enterprise has not caused or contributed to, but which are directly linked to its operations, products or services by a business relationship, the responsibility to respect human rights does not require that the enterprise itself provide for remediation, though it may take a role in doing so. ${ }^{61}$

In traditional criminal law, there are great difficulties in demonstrating the mens rea of the officers or employees of the multinational corporation concerning the adverse impacts, unless one can show a conspiracy or similar arrangement by the multinational to aid and abet the violations by the local supplier. There are similar difficulties in showing legal ('proximate') causation of the adverse impacts by the multinational, because of the independent, purposeful decisions by officials of the local supplier to commit the acts leading to the adverse impacts.

Rules that would hold the multinational corporations and their officials criminally liable for acts of independent local members of the supply chain would go far towards making this group of outsiders into a 'human rights police force' in developing countries. It is not clear which, if any, such countries would welcome this legal development.

\subsection{Jurisdiction to prescribe: Developments}

The National Reports predominantly show the use of traditional bases of jurisdiction over corporations for human rights crimes. To the extent that there is expansion of jurisdiction, it is along the lines required or permitted in treaties covering crimes against international human rights or international humanitarian law. By itself, this is not surprising.

\footnotetext{
60 Ruggie Principles (2011) principles 13, 17-22.

${ }^{61}$ Ruggie Principles (2011) commentary to principle 22; see also commentaries to principles 18-21.
} 


\subsubsection{Universal jurisdiction over corporations: Criminal and civil}

Some have argued that states should be more active in asserting and exercising universal jurisdiction over acts which constitute these crimes. Universal jurisdiction to prescribe and adjudicate concerning acts which are war crimes, crimes against humanity, and genocide is well-established under international law. Torture can today be counted as a universal jurisdiction crime as well. ${ }^{62}$

The European Union amicus brief in Kiobel ${ }^{63}$ argued that universal jurisdiction should apply in appropriate cases whether the particular case involved is criminal or civil, and the defendant in that case was a corporation, Royal Dutch Petroleum. However, amicus briefs in this and other cases show that Australia, the Netherlands, Switzerland, and the United Kingdom (two of which are EU members, one of which is the home state of Royal Dutch Petroleum) have criticized the notion of universal civil jurisdiction. ${ }^{64}$ Universal civil jurisdiction to prescribe and adjudicate in these cases is not universally accepted, even if the state exercising jurisdiction will prescribe law by applying the appropriate substantive international humanitarian law or international human rights law.

Expanding universal jurisdiction, either civilly or criminally becomes even more difficult when the violations are of human rights law rather than international humanitarian law. The human rights law treaties generally do not create general universal jurisdiction over crimes. In particular, the International Bill of Rights (UDHR, ICCPR, and ICESCR) and the International Labour Organization's Declaration on Fundamental Principles and Rights at Work ${ }^{65}$ do not require criminalizing violations at all. One right listed in the ILO Declaration which probably is subject to universal jurisdiction in criminal cases is the prohibition against 'forced or compulsory labour'66 - i.e., slavery.

There is no generally agreed on scheme for what acts causing adverse impacts on these rights - especially by private actors - should be treated as criminal. This issue is beyond the scope of this Report, except to note its difficulty in the absence of a treaty requiring criminalization of certain acts.

Some criminalization treaties require states to extradite persons wanted for the relevant crimes by another state, or else to refer the case for prosecution in their own courts ('extradite

\footnotetext{
62 See Questions Concerning the Obligation to Extradite or Prosecute (Belgium v Senegal), 2012 ICJ Gen. List No. 144, para. 99.

${ }^{63}$ Kiobel, Brief of the European Commission on behalf of the European Union (2012) 17-18, quoted and discussed in OHCHR Working Paper no 2 'State positions on the use of extraterritorial jurisdiction in cases of allegations of business involvement in severe human rights abuses: a survey of amicus curiae briefs filed by States and State agencies in ATS cases (2000-2015)' (2015) 11-12.

${ }^{64} \mathrm{OHCHR}$ Working Paper no 2 'State positions on the use of extraterritorial jurisdiction in cases of allegations of business involvement in severe human rights abuses: a survey of amicus curiae briefs filed by States and State agencies in ATS cases (2000-2015)' (2015) 6.

${ }^{65}$ Ruggie Principles (2011) principle 12 sets these out as the foundation of international human rights law.

${ }_{66}^{66}$ International Labour Organization's Declaration on Fundamental Principles and Rights at Work (1998) para. 2 (b).
} 
or $\operatorname{try})^{\prime} .{ }^{67}$ This subsidiary form of universal criminal jurisdiction is generally accepted, but is not a cure for the lack of primary universal jurisdiction over human rights violations generally.

There is very little state practice applying primary universal jurisdiction to remedy international human rights law wrongs to persons outside the areas of traditional international humanitarian law and probably torture and slavery. As the United States Report shows, the courts of that country have pulled back concerning possible use of the Alien Tort Claims Act to create universal civil jurisdiction even over violations of international humanitarian law.

\subsubsection{Treaties and other international or transnational documents requiring corporate accountability for acts which are crimes for individuals}

A number of treaties and other international or transnational documents require that national law hold corporations and other artificial persons liable in some way for acts which, when committed by individuals, are crimes. These treaties usually allow states to decide whether corporate liability will be criminal, administrative or civil; they may be worldwide or regional. 68 These requirements apply both to states which are generally 'host' states of transnational enterprises and to states which are generally 'home' states of operating entities such as subsidiaries, where many business-related human rights take place.

\subsubsection{Consolidation of objective territoriality}

Objective territoriality has become even stronger as a basis for criminal jurisdiction in recent decades. This appears in most of the criminalization treaties over this period. We also see it in state business regulation practice, where a direct, substantial, reasonably foreseeable (forbidden) economic effect in a country will support prescriptive jurisdiction over anticompetitive actions committed outside the country. ${ }^{69}$ This is reinforced by the non-

${ }^{67} \mathrm{Eg}$, UN Convention against Torture (1984) art 5(2).

${ }^{68}$ Worldwide treaties include: UN International Convention on the Suppression of the Financing of Terrorism (1999) art. 5 (when a person responsible for management and control of the corporation does the act in his/her official capacity; only required to criminalize acts of corporations located in the state party or organized under its laws; liability may be criminal, civil or administrative); UN Convention against Transnational Organized Crime (2000) art 10 (location of corporations which must be held liable not specified; liability may be criminal, civil, or administrative); UN Convention on Corruption (2003) art 26 (location of corporations which must be held liable not specified; liability may be criminal, civil, or administrative). Regional treaties include: Convention on the Protection of the Environment through Criminal Law, ETS No 172 (1998) arts 8, 9 (requiring criminal or administrative sanctions for legal persons); Additional Protocol to the SAARC Regional Convention on the Suppression of Terrorism (2004) art 6 (shall create liability of legal entities, which can be criminal, civil or administrative); CoE Convention on the Prevention of Terrorism (2005) art 10, CoETS, No 196. For non-treaty documents requiring states to create corporate liability, whether criminal or otherwise, for international crimes, see, e.g., UN Security Council Res. 1373, UN Doc. S/RES/1373 (2003) para 1(b); EU Council Framework Decision 2008/913/JHA on Combating Certain Forms and Expressions of Racism and Xenophobia by Means of Criminal Law (2008) art 5 ('held liable').

${ }^{69}$ See EC Wood Pulp Cases (1988); 15 USC sec. 6A (US Foreign Trade Antitrust Improvements Act); US Hartford Fire (1994) ('substantial and intended'). 
criminal private international law rules of many countries, which use the law of the place of the injury or harm as the law defining tort liability.

This is important for host countries of multinational businesses. It means that they have authority to make law, civil or criminal, for those multinationals which direct the activities of both artificial and natural persons within their territories. Where the actual amount of assets held by the multinational's subsidiary or branch or partner in the host state may be small, the ability to hold the parent corporation liable may significantly increase chances of real reparations. ${ }^{70}$

\subsection{Jurisdiction to adjudicate: Developments}

\subsubsection{Treaty law developments}

Some of the newer treaties have requirements that victims of crimes have access to remedies for their victimization, including remedies that might be required to cross borders in order to be effective. The Convention against Corruption requires that states enforce confiscation of proceeds of corruption crimes and instrumentalities of these crimes, ${ }^{71}$ and goes on to require states to take measures to ensure victims have a means for obtaining compensation ${ }^{72}$ (given that full compensation may go beyond restitution of wrongfully taken property). These remedies need not always be part of the criminal matter. ${ }^{73}$

This is a rather recent development in treaty-making, and occurred over the course of making several treaties. The 2000 Convention against Organized Crime requires seizure of proceeds and instrumentalities of crime and suggests using them for compensation, including transnationally. ${ }^{74}$ Its main text does not have the requirement of additional means for achieving full compensation for victims, but its Protocol on Trafficking in Women and Children does and includes a provision on rehabilitation of victims as well. ${ }^{75}$

\subsubsection{Reparations and legality of punishments}

The principle of legality requires that punishments as well as forbidden acts be specified in advance of a crime. Many states consider a sentence outside that specified by statute to be an illegal sentence which can be voided, even if it was agreed to by a defendant, because it was beyond the authority or jurisdiction of the court to impose. This poses some obstacles to courts developing and applying the sort of flexible sanctions imagined by the 2005 Basic Principles and the 2011 Ruggie Principles, at least when the sanctions are applied in criminal cases.

\footnotetext{
${ }^{70}$ See section 3.4 below on developments in enforcement jurisdiction.

${ }^{71}$ UN Convention against Corruption (2003) art 32.

72 UN Convention against Corruption (2003) arts 35, 57(c); cf art 34 (on undoing other consequences of corruption).

${ }^{73}$ International Labour Organization's Declaration on Fundamental Principles and Rights at Work (1998) para 2(b).

${ }^{74}$ UN Convention against Transnational Organized Crime (2000) arts 12(1), 14(2).

75 Protocol to Prevent, Suppress and Punish Trafficking in Persons, Especially Women and Children, supplementing the United Nations Convention against Transnational Organized Crime (2000) art. 6(3 and 6).
} 
A statute allowing a court to determine an amount of money required for full reparation in a criminal case can certainly be written, as can a statute requiring restitution of property taken or otherwise illegally obtained, so long as it is not real property subject to the exclusive jurisdiction of another country. However, the regime suggested by the Ruggie Principles would allow or require remedies beyond the monetary which would require corporations and perhaps individuals convicted of crime to participate in the sorts of activities quoted above from the 2005 Basic Principles. ${ }^{76}$ It may be difficult to write such statutes for criminal penalties without facing the question how flexible criminal penalties can be before they violate the principle of lex certa, that the law be reasonable certain (not vague) and understandable to persons.

It is possible that this issue can be addressed in the criminal context. It will, however, take a great deal of work.

\subsection{Enforcement jurisdiction: Developments}

There are two great problems of enforcement jurisdiction concerning corporate human rights crimes. First is the requirement of permission to act on the territory where assets are held. Second is the practice of forbidding enforcement of another state's penal laws.

The 2005 UN Guiding Principles indicate that states should allow enforcement of judgments of other states which provide reparations for human rights violations:

17. States shall, with respect to claims by victims, enforce domestic judgements for reparation against individuals or entities liable for the harm suffered and endeavour to enforce valid foreign legal judgements for reparation in accordance with domestic law and international legal obligations. To that end, States should provide under their domestic laws effective mechanisms for the enforcement of reparation judgements. ${ }^{77}$

Domestic judgments enforced domestically do not raise international law issues of jurisdiction to enforce. Nonetheless, fear of states' unwillingness to enforce their own courts' judgments against themselves or powerful business interests led to this provision. It is an echo of provisions of some human rights treaties requiring that national remedies for human rights violations be enforced, at least within the state whose judiciary gave the remedy. ${ }^{78}$ Similar provisions also appear in some of the human rights treaties requiring that violations be criminalized, such as the Convention against Torture. ${ }^{79}$

\footnotetext{
76 See section 1 above, quoting UN Basic Principles (2005) paras 19-23.

77 UN Basic Principles (2005) para 15.

78 ICCPR (1966) art 2(3)(c) (enforcement of national judicial remedies); ACHR art 25(2)(c) (same); see ECHR (1950) art 13 (remedy must be 'effective').

79 UN Convention against Torture and Other Forms of Cruel, Inhuman or Degrading Treatment or Punishment (1984) art 14(1) (compensation, including rehabilitation for torture survivors; compensation for dependents of victims killed by torture).
} 
Some National Reports show compensation among available criminal penalties or that criminal penalties may be imposed without prejudice to repair of damages caused..$^{80}$.

Many reparations judgments may need to be enforced transnationally. The persons, natural or legal, against whom they are issued may not have property to seize in the jurisdiction in which the judgment is issued. When a state where a transnational enterprise is operating issues a judgment against the parent corporation from another state, it is quite likely that the judgment will need to be enforced in the state of incorporation or the state of its principal place of business or another state where it holds assets. Where necessary remedies include systematic change in the way the enterprise does business, effective orders may need to be entered in both in the host state where operations occur and the home state of the parent.

\subsubsection{Enforcing judgments, especially criminal judgments, across borders today}

The traditional rules continue to exist. The rule against one state acting on the territory of another without permission remains intact. The rule against enforcement of another state's criminal law and criminal judgements continues to exist as a general rule, except where modified by treaty, statute, or other law.

There has been some progress. Some treaties require states to cooperate in enforcing criminal judgments seizing or forfeiting property. ${ }^{81}$ The worldwide treaties to this effect address particular crimes, rather than providing an overall framework for obtaining funds for reparations. The problems raised by judgments subjecting corporations to criminal sanctions in one country which must be enforced in a country which applies only administrative or civil sanctions to corporations remain unresolved.

The Convention against Corruption speaks most directly to both the problem not being able to act on the territory of another state and the problem of not enforcing another state's criminal laws. It has elaborate provisions for state cooperation in identifying and seizing property. ${ }^{82}$ These provisions require states to conform their laws, in effect, to allow the forfeiture and seizure portions of foreign criminal judgments concerning crimes of corruption to be enforced through their legal systems.

States must make legal persons subject to 'criminal, civil or administrative' liability for participation in criminal acts under the convention. ${ }^{83}$ Provisions for forfeiture or confiscation of asserts which are the proceeds of criminal activity appear to require states where property is found to establish laws allowing seizures of this property without regard to whether the

80 Austria Report sec. 2.I.1.a., discussing Law on the Responsibility of Corporations ('Verbandsverantwortlichkeitsgesetz', VbVG, BGBl I 2005/151, in force since 2006) secs 4-6; cf. Brazil Report, sec. 1.1.1, citing Brazil Constitution art. 225 (stating that penalties for environmental crimes may be imposed 'without prejudice to the obligation to repair the damages caused').

81 See UN Convention against Corruption (2003) arts 31, 35 (on private victims), and chap. V (on asset recovery); EU Framework Decision 2005/214/ JHA on the Application of the Principle of Mutual Recognition to Financial Penalties (2005) art. 5; EU Framework Decision 2006/783/)HA on the Application of the Principle of Mutual Recognition to Confiscation Orders (2006), art. 6.

82 UN Convention against Corruption (2003) pt. V, especially art 55. See also UN Convention against Illicit Traffic in Narcotic Drugs and Psychotropic Substances (1988) (not addressing human rights issues).

${ }^{83}$ UN Convention against Corruption (2003) art 26. 
property is held by a corporation or an natural person, whether the judgment being enforced is civil or criminal, or whether the state where the property is located criminalizes acts of corporations. ${ }^{84}$ It requires states where assets are held 'to permit another State Party to initiate civil action in its courts' to establish its ownership of property, and to allow such a State Party to request an order against those who have 'committed offences' to pay compensation to the victim state. ${ }^{85}$ It also must adopt procedures allowing its authorities to give effect to confiscation orders of another State Party. ${ }^{86}$ These provisions, however, are subject to the requested state's 'domestic law' or 'domestic legal system' ${ }^{.87}$ This leaves open to debate the question whether a state may refuse to enforce foreign criminal judgment provisions against corporate assets held on its territory on the grounds that its law or legal system does not recognize the concept of corporate criminality.

The 1999 Convention on the Suppression of Terrorist Financing has similar, but less detailed, provisions. ${ }^{88}$ The question of enforcement of a criminal judgment against a corporation in a state which does not recognize corporate criminality is left open in this treaty as well, by language that measures shall be taken 'in accordance with its domestic legal principles' ${ }^{89}$ It is not clear at this point how well these provisions have been implemented in the national law of states in which assets are likely to be found.

The Convention against Corruption urges, but does not require, that the seized assets go to reparations to victims. States must give 'priority consideration' to returning the property to the victims of crimes of corruption who are in other states. ${ }^{90}$ The Convention on the Suppression of Terrorist Financing suggests that states consider mechanisms for sharing funds with other states and compensating victims of terrorism out of seized assets. ${ }^{91}$

The EU has a more general approach. It has issued two directives on recognition throughout the EU of criminal judgments applying financial penalties and forfeitures of property. ${ }^{92} \mathrm{It}$ has also issued a directive requiring prompt return of property to victims of crime and consideration of requiring compensation of offenders, along with requiring procedures to enable victims from other EU states to make their claims in the place of prosecution. ${ }^{93}$ Unfortunately, this procedural requirement does not apply to persons from outside the EU who are victims of human rights violators being prosecuted in the EU.

\footnotetext{
${ }^{84}$ UN Convention against Corruption (2003) arts 53-55.

${ }^{85}$ UN Convention against Corruption (2003) art 53.

${ }^{86}$ UN Convention against Corruption (2003) art 54.

${ }^{87}$ UN Convention against Corruption (2003) arts 53-55.

88 UN Convention on the Suppression of Terrorist Financing (1999) arts 5, 8.

89 UN Convention on the Suppression of Terrorist Financing (1999) art 8.

${ }^{90}$ UN Convention against Corruption (2003) art 57(c).

91 International Convention for the Suppression of the Financing of Terrorism (2000) art 8(3 and 4).

92 EU Framework Decision 2005/214/ JHA on the Application of the Principle of Mutual Recognition to Financial Penalties (2005) art 5; EU Framework Decision 2006/783/JHA on the Application of the Principle of Mutual Recognition to Confiscation Orders (2006) art 6.

${ }^{93}$ Directive 2012/29/EU establishing minimum standards on the rights, support and protection of victims of crime (2012) arts 15-17, implementing Treaty on the Functioning of the European Union art 82(2).
} 
Some newer bilateral Mutual Legal Assistance Treaties (MLATs) provide for enforcement of criminal fine, forfeitures and/or restitution. ${ }^{94}$ Some states have statutory provisions governing forfeiture, seizure, and confiscation as matters of mutual legal assistance either by treaty or, sometimes, without treaty based on reciprocity..$^{95}$

\subsubsection{Form of the judgment: criminal or civil}

The EU Recast Brussels I Regulation shows the importance of form to the exercise of enforcement jurisdiction in transnational cases. In criminal cases where the victim is treated as a civil party, a judgment in favor of the victim is treated as a trans-nationally enforceable civil judgment. This becomes clear from the definition of a 'judgment' in the Regulation, ${ }^{96}$ the subsection on jurisdiction related to criminal cases, ${ }^{97}$ and the rejection of jurisdiction as a 'public policy' ground for refusing recognition and enforcement of judgments. ${ }^{98}$

The Regulation does not apply to criminal judgments concerning the rights of victims who are not civil parties. It also does not apply to 'administrative matters', ${ }^{99}$ thus appearing to exclude decisions from the 'criminal administrative responsibility' system described in the Italy National Report or the German 'administrative fine' system described in the Germany National Report. In any event, this Regulation applies only to recognition of judgments issued within the EU and a few associated non-member states.

In many non-EU states, the prohibition of recognition of foreign criminal judgments remains. Foreign civil money judgments may be recognized under certain conditions defined by national law.

\subsubsection{Enforcement jurisdiction and non-monetary reparations}

Non-monetary judgments and orders are often difficult to enforce in other states. This is especially true in criminal cases, though it often applies in civil cases as well. For example, in the United States, statutory reform allowing courts to recognize and enforce monetary judgments from the courts of other countries does not extend to non-monetary judgments and orders. ${ }^{100}$ Some states (in the international-law sense) will recognize many nonmonetary civil judgments. ${ }^{101}$

${ }_{94}$ Kevin M Stephenson, et al, Barriers to Asset Recovery (World Bank, 2011), appendix B, available at http://documents.worldbank.org/curated/en/204221468338390474/pdf/632580PUBOBarr0ID0186600BOX3615 12B0.pdf, contains extensive citation to these sources from a sampling of countries.

95 See generally Stephenson, et al (2011), appendix B.

${ }^{96}$ EU Regulation No 1215/2012 of 12 December 2012 on jurisdiction and the recognition and enforcement of judgments in civil and commercial matters (recast) (Recast Brussels I) art 2(a).

${ }^{77}$ Recast Brussels I art 7(3).

98 Recast Brussels I arts 45(3) 46.

${ }_{99}$ Recast Brussels I art 1(1).

100 See Uniform Enforcement of Foreign Money Judgments Act (1948) (adopted in about 16 US states, written by Uniform Law Commission, an expert body appointed by the state governments to present draft statutes harmonizing law).

101 Ralf Michaels 'Recognition and Enforcement of Foreign Judgments' in Max Planck Encyclopedia of Public International Law (2009) p 3, <www.mpepil.com>. 
Suppose one form of reparation awarded in the state of conviction (state $A$ ) is the requirement that corporation A rebuild schools, etc., in another country (state B) destroyed when land was confiscated. There will often be great difficulty in enforcing this sort of judgment.

Even if corporation A wishes to comply with the order, it may often need to get various permissions and licenses from state $B$. As a result, a judgment requiring such a remedy may need to be negotiated among state $B$, corporation $A$, and the victims of the crime in state $B$. It may also require the approval of the court in state $\mathrm{A}$ which is hearing the case.

\subsubsection{Summary: Massive national reform needed for effective enforcement of reparations}

There has been some progress to overcoming problems of enforcement of judgments, whether made in civil or criminal cases, for purposes of providing reparations for corporate violations of human rights and international humanitarian law. Nonetheless, as we have seen, the traditional rules against transnational enforcement of criminal judgments and the limited nature of transnational enforcement of civil judgments still pose tremendous obstacles to effective remedies. Even in those treaties which require states to cooperate in enforcing criminal judgments, it is not completely clear what is to be done when the state doing the enforcing does not have criminal liability of corporations in its domestic law.

Given that these roadblocks are based in the traditions of national law around the world, solutions must be found in the national law of states whose people are victimized by human rights and humanitarian law violations. International consensus documents and treaties can help, but eventually, these instruments must be transferred into effective national law.

\section{Conclusion}

One cannot be too optimistic about criminal and quasi-criminal jurisdiction over corporate human rights abuses leading to a great increase in reparations to victims. In the countries covered by the National Reports, this has not happened yet. ${ }^{102}$

Today, in many cases, civil actions may be more likely to produce reparative justice for victims of transnational human rights abuses than criminal actions. In French-style civil law jurisdictions, the definition of 'civil action' may include action as a partie civile connected to a criminal case.

This conclusion is connected to the limitations on criminal sanctions on corporate entities both what they are and how they can be enforced. It also suggests that the separation of corporate parent and subsidiary identity - part of international law when the two corporations have different national characters - remains an obstacle to a coherent scheme for overall enterprise liability for human rights abuses.

The Ruggie Principles' emphasis on voluntary monitoring and remediation of human rights abuses by corporations holds some hope. However, if it is to succeed, it must be backed up

\footnotetext{
${ }^{102}$ Australia Report, China Report, Germany Report, Italy Report each report no cases or almost no cases being brought.
} 
by effective legal sanctions for these abuses, as all of the United Nations documents recognize.

The voluntary monitoring and remediation scheme will work best if it implemented at the local level, in the host states of multinational businesses. Indeed this may be the only way that it can work effectively.

New developments in jurisdictional law may prove useful here. The consolidation of objective territorial jurisdiction in new treaties against transnational crime means that host states are in a stronger position to exercise judicial authority over transnational parent corporations as well as local subsidiaries. State use of objective territoriality is permissible in customary international law, given how widespread the doctrine is in national criminal law and its long general acceptance by states. Crimes which are also human rights violations are no exception. This means that states on whose territory human rights crimes are consummated, where victimization occurs, are coming to be in a stronger position to prosecute those individuals and parent corporations which, acting outside, caused or aided the violations. Mutual Legal Assistance regimes (treaties and/or statutes) with asset forfeiture, confiscation, and recovery provisions may make criminal judgments including remedial provisions enforceable across borders.

This increased host state authority should encourage voluntary corporate compliance by entire multinational enterprises. Implementing this authority effectively will depend on capacity building efforts by host states themselves, in cooperation with developed states, international organizations, and the private and NGO sectors.

\section{Selected Literature}

Bassiouni M C, 'Introduction to Recognition of Foreign Penal Judgments,' in M Cherif Bassiouni, ed, International Criminal Law, vol. II (Multilateral and Bilateral Enforcement) (3rd ed, 2008)

Doyle C, Corporate Criminal Liability: An Overview of Federal Law, (US Congressional Research Paper 2013)

Gallant K S, The Principle of Legality in International and Comparative Criminal Law (Cambridge Univ Press 2009).

Mann FA, The Doctrine of International Jurisdiction Reconsidered after Twenty Years, Recueil des cours vol 186, pp 1, 54 (1984)

Michaels R, 'Recognition and Enforcement of Foreign Judgments' in Max Planck Encyclopedia of Public International Law (2009) <www.mpepil.com>.

Träskman P O, 'Should We Take the Requirement of Double Criminality Seriously?' in Nils Jareborg, Double Criminality (Iustus Förlag 1989)

Zerk J, 'Corporate liability for gross human rights abuses: Towards a fairer and more effective system of domestic law remedies' (UN OHCHR (2014)). 